\title{
Water Quality and Environmental Technology
}

\author{
Vassilios A. Tsihrintzis ${ }^{1}$
}

Published online: 17 November 2018

(C) Springer Nature Switzerland AG 2018

This special issue of Environmental Processes includes 15 selected papers presented in the 10th World Congress on Water Resources and Environment, "Panta rhei", of the European Water Resources Association (EWRA). The Congress was held in Athens, Greece, 5-9 July 2017 (http://ewra2017.ewra.net). EWRA organizes this series of international congresses every two years. The aim of the Congress was to promote environmentally sustainable water resources management and assist in improving the capacity of countries to mitigate and adapt to climate change and natural hazards.

The task of the organisation of the Congress was undertaken by the Centre for the Assessment of Natural Hazards and Proactive Planning and the Laboratory of Reclamation Works and Water Resources Management of the School of Rural and Surveying Engineering of the National Technical University of Athens. For the first time, the Congress was co-organized by the Environmental and Water Resources Institute of the American Society of Civil Engineers, in an effort to establish a constructive dialogue between Europe and America on water resources and environmental issues. The Congress organization coincided with the 30 -year anniversary of Water Resources Management, the official journal of EWRA published by Springer.

The Congress comprised the following nine specialized conferences:

- Advances in Hydrological Processes

- Climate and Water Resources

- Water Resources Management

- Droughts and Water Scarcity

- Water Quality and Environmental Processes

- Urban Water Networks

- Agricultural Water Management

- Groundwater Hydrology and Contamination

- Legislation and Policies

Vassilios A. Tsihrintzis

tsihrin@central.ntua.gr; tsihrin@survey.ntua.gr; tsihrin@otenet.gr

1 Centre for the Assessment of Natural Hazards and Proactive Planning \& Laboratory of Reclamation Works and Water Resources Management, Department of Infrastructure and Rural Development, School of Rural and Surveying Engineering, National Technical University of Athens, 9 Iroon Polytechniou St., 15780 Zografou, Athens, Greece 
As seen, these conferences covered a wide range of modern topics on water resources and the environment. Key issue behind these topics was the non-stationarity of variables and processes, which is delineated by the saying of the ancient philosopher Heraclitus "Panta rhei," which means "everything flows."

The Congress was a benchmark event, where a large number of scientists and engineers from fifty countries and cultures around the world were gathered, interacted and explored ways to face the old and new global and regional challenges on water resources and ecosystems, for the benefit of the present and future generations. High quality papers were presented in oral and poster form, which have significantly contributed to the multidisciplinary and global context of the Congress. As a notice, the next EWRA congress, the 11th World Congress on Water Resources and Environment, will have the general theme "Managing Water Resources for a Sustainable Future" and will be held in Madrid, Spain, 25-29 June 2019 (http://ewra2019.ewra.net/).

This special issue of Environmental Processes, with the title "Water Quality and Environmental Technology", was guest-edited by Professor Athanasios Loukas (Aristotle University of Thessaloniki, Thessaloniki, Greece) and Dr. Dimitris Tigkas (National Technical University of Athens, Athens, Greece). Originally, 39 papers presented at the conference were pre-selected for peer review and possible publication in the journal. The authors were notified to expand the paper and submit it for peer review. Finally, the following 15 papers passed the journal's peer-review process and made it to publication. The topics dealt in these papers are briefly presented below.

Ioannidou and Pearson (2018) conducted tracer tests in six full-scale systems in the UK, which operated under different flow regimes, operational depths, shapes and sizes, and inlet/ outlet configurations. The aim was to quantify the hydraulic performance and mixing characteristics of pond/constructed wetlands treatment units. Among others, they found variations in residence times up to a factor of 3, and the width was found more important for efficiency than depth.

Manentia et al. (2018) combined Residence Time Distribution (RTD) analysis with Computational Fluid Dynamics (CFD) analysis to detect possible hydrodynamic defects, i.e., bypass and dead volume, influencing process efficiency in biological wastewater treatment systems. The method was tested in an activated sludge pilot plant, and was found effective in detecting defects and their location.

Awolusi et al. (2018) investigated the ammonia oxidizing bacteria (AOB) community distribution in a full-scale wastewater treatment plant (WWTP) using barcoded 454pyrosequencing targeting the ammonia monooxygenase alpha subunit (amoA) gene. They also quantified the $\mathrm{AOB}$ population using the quantitative polymerase chain reaction (qPCR) technique. Among others, the study revealed that a vast population of novel, ecologically significant and unexploited AOB species exist in activated sludge communities. The nitrification rate of the plant was also found to have significant correlation with AOB population abundance and temperature.

Kolliopoulos et al. (2018) evaluated two low energy water recovery technologies in the chemical industry: Forward Osmosis (FO) and Freeze Crystallization (FC). The economic effectiveness of an FO process using trimethylamine- $\mathrm{CO}_{2}-\mathrm{H}_{2} \mathrm{O}$ as concentrated draw solution (CDS) was evaluated. The study identified optimum operating conditions for the separation of the draw solutes from the product water and the most important parameters that affect its performance. With respect to the $\mathrm{FC}$ process, the natural freezing of a $0.5 \mathrm{~m} \mathrm{MgSO}$ aqueous 
solution was studied at freezing temperatures ranging from $-2{ }^{\circ} \mathrm{C}$ to $-26{ }^{\circ} \mathrm{C}$, while melting of the recovered solid, i.e., ice with entrapped solute contamination, was done at room temperature $\left(25^{\circ} \mathrm{C}\right)$ and at $3{ }^{\circ} \mathrm{C}$.

Ji et al. (2018) comparatively tested in a bench-scale direct contact membrane distillation unit the performance of hydrophobic polytetrafluoroethylene and polyvinylidene fluoride membranes in treatment of selected compounds of textile wastewater (e.g., phenol, aniline, and sulfanilic acid), and investigated the effect of various operational parameters, i.e., temperature, flow rate, and concentration. Increased feed temperature and faster cross flow velocity were related with increased performance. The polytetrafluoroethylene membranes performed better that the polyvinylidene fluoride membranes. The process was found promising in treatment of textile wastewater.

Bezirgiannidis et al. (2018) evaluated the performance of a pilot-scale hollow fiber submerged membrane bioreactor in biological treatment of a low carbon/nitrogen (COD/TKN) ratio domestic wastewater under various operating conditions, which included alternating aeration, periodic feeding and external organic carbon source addition, and three COD/TKN ratios. Very high $\mathrm{BOD}, \mathrm{COD}, \mathrm{TKN}$ and $\mathrm{NH}_{4}{ }^{+} \mathrm{N}$ removal efficiencies were found. Denitrification was enhanced by adding glycerol. The quality of the effluent was suitable for unlimited reuse.

Korfali and Karaki (2018) determined metal speciation in the soils of the upper Litani river basin and computed pollution indices for risk assessment. The analysis indicated that $\mathrm{Mn}, \mathrm{Zn}$, $\mathrm{Cr}$, and As had their highest average percentage from total metal in the reducible and acid soluble soil fractions, while $\mathrm{Cu}, \mathrm{Ni}, \mathrm{Cd}, \mathrm{Hg}$ were in the oxidizing and acid soluble soil fractions. Very strong contamination was found for $\mathrm{Cd}$ and $\mathrm{Hg}$, and high risk for $\mathrm{Cr}, \mathrm{Ni}$, and Cd. Finally, $50 \%$ of the sampled sites suffered from considerable contamination.

Li et al. (2018) measured major ions and isotopes of hydrogen and oxygen in lake, river and spring water samples collected in Tajikistan. Among others, $\mathrm{Ca}^{2+}$ and $\mathrm{HCO}_{3}{ }^{-}$were found the dominant ions of river and spring waters, originating mainly from carbonate weathering. Most lakes were found of the $\mathrm{Mg}_{-} \mathrm{SO}_{4}{ }^{2-}$ and $\mathrm{Na}-\mathrm{Cl}^{-}$type, reflecting persistent, long-term evaporation under an arid climate. The hydrogen and oxygen isotope values of river and spring water indicated supply mainly by glaciers in the east and by precipitation in the west.

Mavromati et al. (2018) analyzed physicochemical data from the national monitoring network of waters in Greece, which comprises 50 natural and artificial lake water bodies. The aims were to present the pressures resulting from land cover and population density, and to link catchment area features with physicochemical parameters.

Gitau et al. (2018) evaluated weather generator representation of climate extremes, focusing on LARS-WG applied to three stations in the Western Lake Erie Basin, USA. Overall, they found relatively good performance of this generator in representing extremes within the basin.

Gerbens-Leenes (2018) compared water footprints (WFs) of first, second and third generation bioenergy, and WFs of future bioenergy demand based on different bioenergy feedstocks.

Tsakmakis et al. (2018) used FAO's AquaCrop and CROPWAT models and two water footprint (WF) methodological frameworks to assess the impact of irrigation technology and strategy on the reduction of cotton WF in Northern Greece. Among others, results showed that drip irrigation could reduce the total WF by $5 \%$, when compared to sprinkler irrigation. Also, deficit irrigation could reduce the total WF by roughly $12 \%$, when compared to full irrigation. Finally, the green WF was approximately $55 \%$ of the total.

Gülbaz and Kazezyllmaz-Alhan (2018) investigated the implementation of low-impact development (LID) measures on total suspended solids (TSS) in Alibeyköy Watershed, 
Istanbul, Turkey, through the application of the hydrologic-water quality model EPA-SWMM. Bioretention, vegetative swales, permeable pavements, and infiltration trenches were found to significantly reduce TSS both in case of distinct and combined implementations; however, bioretention and vegetative swales were slightly more effective.

Bariamis et al. (2018) conducted a land accounting study at the national level of Greece and in the 14 river basin districts (RBDs), aiming to reveal the main drivers of change in land cover stocks, as well as future trends. Results showed that over the last 23 years significant piece of land has been transformed into urban fabric and other artificial surfaces in all RBDs. An attempt made to estimate trends in the next 50 years showed $+17 \%$ expansion of urban fabric and significant loss of natural areas.

Papageorgaki and Nalbantis (2018) investigated the spatio-temporal variation of Critical Support Area (CSA) in three river basins in mainland Greece, for both wet and dry seasons of the hydrological year. Based on stepwise regression analysis, the ground slope for the upslope contributing area was found to better predict CSA; however, predictability was still low.

Publisher's Note Springer Nature remains neutral with regard to jurisdictional claims in published maps and institutional affiliations.

\section{References}

Awolusi O, Kumari S, Bux F (2018) Evaluation of ammonia oxidizing bacterial community structure of a municipal activated sludge plant by 454 high-throughput pyrosequencing. Environ Process. https://doi. org/10.1007/s40710-018-0319-2

Bariamis G, Paschos G, Baltas E (2018) Land accounts in the river basin districts of Greece. Environ Process. https://doi.org/10.1007/s40710-018-0321-8

Bezirgiannidis A, Marinakis N, Ntougias S, Melidis P (2018) Membrane bioreactor performance during processing of a low carbon to nitrogen ratio municipal wastewater. Environ Process. https://doi. org/10.1007/s40710-018-0317-4

Gerbens-Leenes PW (2018) Green, blue and grey bioenergy water footprints, a comparison of feedstocks for bioenergy supply in 2040. Environ Process. https://doi.org/10.1007/s40710-018-0311-x

Gitau MW, Mehan S, Guo T (2018) Weather generator effectiveness in capturing climate extremes. Environ Process. https://doi.org/10.1007/s40710-018-0291-x

Gülbaz S, Kazezyılmaz-Alhan CM (2018) Impact of LID implementation on water quality in Alibeyköy watershed in Istanbul, Turkey. Environ Process. https://doi.org/10.1007/s40710-018-0318-3

Ioannidou VG, Pearson JM (2018) Hydraulic \& design parameters in full-scale constructed wetland \& treatment units: six case studies. Environ Process. https://doi.org/10.1007/s40710-018-0313-8

Ji MY, Chen HT, Xia Q, Li F, Liu YB (2018) Treatment of typical organic pollutants in textile wastewater by direct contact membrane distillation. Environ Process. https://doi.org/10.1007/s40710-018-0292-9

Kolliopoulos G, Shum E, Papangelakis VG (2018) Forward osmosis and freeze crystallization as low energy water recovery processes for a water-sustainable industry. Environ Process. https://doi.org/10.1007/s40710-018-0316-5

Korfali SI, Karaki H (2018) Speciation of metals in soils and water: risk assessment. Environ Process. https://oi. org/10.1007/s40710-018-0328-1

Li QY, Wu JL, Shen BB, Zeng H, Li YH (2018) Water chemistry and stable isotopes of different water types in Tajikistan. Environ Process. https://doi.org/10.1007/s40710-018-0312-9

Manentia S, Todeschini S, Collivignarelli MC, Abbà A (2018) Integrated RTD - CFD hydrodynamic analysis for performance assessment of activated sludge reactors. Environ Process. https://doi.org/10.1007/s40710-018-0288-5

Mavromati E, Kagalou I, Kemitzoglou D, Apostolakis A, Seferlis M, Tsiaoussi V (2018) Relationships among land use patterns, hydromorphological features and physicochemical parameters of surface waters: WFD lake monitoring in Greece. Environ Process. https://doi.org/10.1007/s40710-018-0315-6

Papageorgaki I, Nalbantis I (2018) On spatio-temporal modelling of stream network initiation. Environ Process. https://doi.org/10.1007/s40710-018-0338-z

Tsakmakis ID, Zoidou M, Gikas GD, Sylaios GK (2018) Impact of irrigation technologies and strategies on cotton water footprint using AquaCrop and CROPWAT models. Environ Process. https://doi.org/10.1007 /s40710-018-0289-4 